\title{
Ecological Structure and Prediction Equations for Estimating Tree Age, and Dendometric Parameters of Acacia senegal in the Senegalese Semi-Arid Zone-Ferlo
}

\author{
Aly Diallo ${ }^{1}$, Emile Codjo Agbangba ${ }^{1,2}$, Ousmane Ndiaye ${ }^{1}$, Aliou Guisse ${ }^{1,3}$ \\ ${ }^{1}$ Département de Biologie Végétale, Faculté des Sciences et Techniques, Université Cheikh Anta Diop, Dakar-Fann, Sénégal; \\ ${ }^{2}$ Department of Crop Science, Faculty of Agronomy, University of Parakou, Parakou, Benin; ${ }^{3}$ Université Cheikh Anta Diop, \\ Observatoire Homme Milieu Tessekeré (CNRS \& UCAD), Dakar, Sénégal. \\ Email: alguisse@orange.sn
}

Received March $7^{\text {th }}, 2013$; revised April 25 ${ }^{\text {th }}, 2013$; accepted May $10^{\text {th }}, 2013$

Copyright (C) 2013 Aly Diallo et al. This is an open access article distributed under the Creative Commons Attribution License, which permits unrestricted use, distribution, and reproduction in any medium, provided the original work is properly cited.

\begin{abstract}
The development of equations to predict tree height, crown diameter, crown depth from stem diameter of a tree species enables arborists, researchers, and urban forest managers to model costs and benefits, analyze alternative management scenarios, and determine the best management practices for sustainable forests. The objective of this study was to develop regression prediction models for tree age, tree height, crown diameter, crown ratio and crown depth for $A$. senegal growing in Ferlo, in the northern Senegal. Four plantations of different years old (ISRA, 10 years old plantations, Ndodj, 8 years old plantations, Boulal, 5 years old plantations and Déali, 4 years old plantations) were selected. The following dendometric variables: crown height, crown diameter, stem diameter at the breast height, stem basal diameter $($ at $0.30 \mathrm{~m})$ and the height from the tree base to first branch were measured on a total of 489 trees. The results suggested that the ecological structure of the different year old A. Senegal plantation revealed a bell-shaped form with left dissymmetric distribution indicating a predominance of individuals with small diameter at breast height. Allometry study of A. Senegal showed highly significant positive correlations $(p=0.00)$ between stem diameter at breast height, stem basal diameter, tree height, crown diameter and crown depth. Positive correlations were also found between crown diameter, tree height and crown height. Prediction models derived from these relationships can be used to estimate the tree height, stem diameter at breast height and crown depth from crown diameter with greater precision. As for $A$. Senegal age estimation, the established model is not strong as it can explain only $49.1 \%$ of the age variation.
\end{abstract}

Keywords: Ecological Structure; Stem Diameter at Breast; Stem Basal Diameter; Crown Diameter; Crown Depth; Tree Height; Age; Correlation; Regression; Acacia senegal; Northern Senegal

\section{Introduction}

The arabic gum tree Acacia senegal (L.) Willd is a legume belonging to Mimosaceae family [1]. It presents a large distribution in the dry and semi-arid tropical regions of Africa [2]. Its area of distribution spreads mainly from Senegal to Sudan but can be met also in southern Africa and in the Indian subcontinent [3]. Among the many species of genus Acacia used in the agro-silvopastoral Sahel, Acacia senegal has a natural distribution located in the Sahel region receiving an average annual rainfall between 150 and $600 \mathrm{~mm}$ [4]. In Senegal, it is mainly found in the northern part of the country corresponding to the Ferlo. The gum is also very interesting for the production of Arabic gum, the aerial extra fodder and fire- wood or service. Other uses include the restoration of soil fertility by fixing atmospheric nitrogen, providing wood for fuel, building poles for local barriers [5]. It alone provides about $90 \%$ of the world arabic gum production [6]. The average annual production in Senegal is between 500 and 2000 tons with about $240 \mathrm{~kg}$ per hectare [7]. Productivity is so low due to overexploitation by local people, a persistent lack of rainfall, grazing and trampling by livestock making any random natural regeneration.

In general, trees show considerably variation and flexibility in their size of crowns, height and stem diameters [8]. The size of a tree canopy and its height above the ground is significant to a tree in that it determines the total amount of light that the tree intercepts for photo- 
synthesis. The tree stem size has its own adaptive significance to a tree. It must be strong enough to withstand the forces that act on it. These forces are the weight of the tree and the drag exerted on it by the wind [9]. Growth and yield of trees are modeled using stem diameter-at-breast height relationships with tree height, crown height, and crown diameter [10]. The crown is the center of physiological activity, particularly gas exchange, which drives growth and development. Tree crowns also directly influence fire susceptibility, physical stability, and microclimate [11]. Among the major aspects of crown morphology, crown ratio, (defined as the ratio of crown diameter to tree height) is considered as one of the most important, since it strongly influences light interception and growth [12]. Tree crown parameters have been used as predictor variables in diameter and height growth equations. Tree crown ratio can be predicted directly from tree variables such as total height and stem diameter at the breast height [12]. Stem diameter at breast height is an important tree characteristics and an accurate prediction of tree dimensions. It has become prominent as analysis techniques, models, and other statistical tools to allow for the rapid evaluation of extensive volumes of data [13]. Total tree height, crown ratio and crown diameter could be estimated by means of stem diameter, which is easy to measure for the studies in ground-based forest inventory and stand structure determination [13]. The relationship between stem diameter at the breast height and the total tree height is fundamental for developing growth and yield models for forest stands. Height and stem diameter are needed to estimate timber volume, site index, and in forest growth and yield models [12]. Tree height-diameter equations are required by forest resource managers to obtain accurate yield estimations. These estimates are used for decision making processes in forest management. When actual height measurements are not available, height-diameter functions can also be used to predict height growth indirectly [12]. Height-diameter relationships of a given species depend on local environmental conditions and vary within a geographic region [8]. The development of equations to predict tree height, crown diameter, crown height from stem diameter of a tree species will enable arborists, researchers, and urban forest managers to model costs and benefits, analyze alternative management scenarios, and determine the best management practices for sustainable forests [10]. Dendometric parameters vary with the tree age. Several studies have tried to improve the accuracy of the assessment of the age of wood in general [14-17] and especially Acacia senegal [18]. But all the techniques used, such as the use of growth rings, the extraction of cores increases or entire cross sections are destructive and inappropriate for degraded ecosystems to which the development of less destructive methods remains a major challenge.

The objective of this study was to develop regression prediction models for tree age, tree height, crown diameter, crown ratio and crown depth for $A$. senegal growing in Ferlo, in the northern Senegal.

\section{Material and Methods}

\subsection{Sites Location}

Ferlo is located between latitudes $15^{\circ}$ and $16^{\circ} 30^{\prime}$ north and longitudes $13^{\circ} 30^{\prime}$ and $16^{\circ}$ west. It extends from the Senegal River Valley to the fringes of the Groundnut Basin over $60,000 \mathrm{~km}^{2}$ [19]. At the administrative level, the Ferlo region covers part of Saint Louis and Louga and the entire Matam region (Figure 1). Ferlo area belongs to the Sahelian zone characterized by the alternation of two seasons: a dry season that lasts nine months (October to June) and rainy season of 3 months. The rainfall is low and highly unstable with an average of $422.6 \mathrm{~mm}$ per year with a coefficient of variation of 0.3 over the period 1951-2004 [20]. The average temperature hovers around $27.73^{\circ} \mathrm{C}$, it fluctuates between a maximum average of $30.19^{\circ} \mathrm{C}$ in October and a minimum of $24.48^{\circ} \mathrm{C}$ in January [21]. On the morpho-pedological way, the study area belongs to the sandy Ferlo characterized by a succession of dunes and shallow little rough with a different soil type depending on whether you are on a high dune or low slope [22]. Indeed, the bottoms have clay content higher than the tops of the dunes.

The study was conducted in four sites in Ferlo: The plantation of ISRA in 1999 which is located in the Centre of Animal Research of Dahra (CRZ) to ten kilometers east of the city, the plantation of Ndodj in 2001 located approximately $24 \mathrm{~km}$ north-east, the plantation of Boulal in 2004 at $20 \mathrm{~km}$ west and the plantation of Deali in 2005 of about $45 \mathrm{~km}$ south-west (Figure 1). The sites choice was motivated by the existence of a north-south gradient (Ndodj-deali), the geomorphology of the land and the level of protection. Plantations of ISRA and Deali are characterized by an alternation of dunes, depressions and shelf areas whereas Ndodj is characterized by a flat topography and Boulal 2004 is marked by small cons slacks. ISRA plantation was fully protected (regular monitoring) unlike Deali plantation. Access to ISRA and Boulal plantations is limited while Ndodj is partially protected.

\subsection{Trees Sampling and Measurement}

The Acacia senegal studied plantations varied in ages. Dendrometric statements were made on a total of 18 square plots of $625 \mathrm{~m}^{2}$ each $([23,24])$. They were ran- 

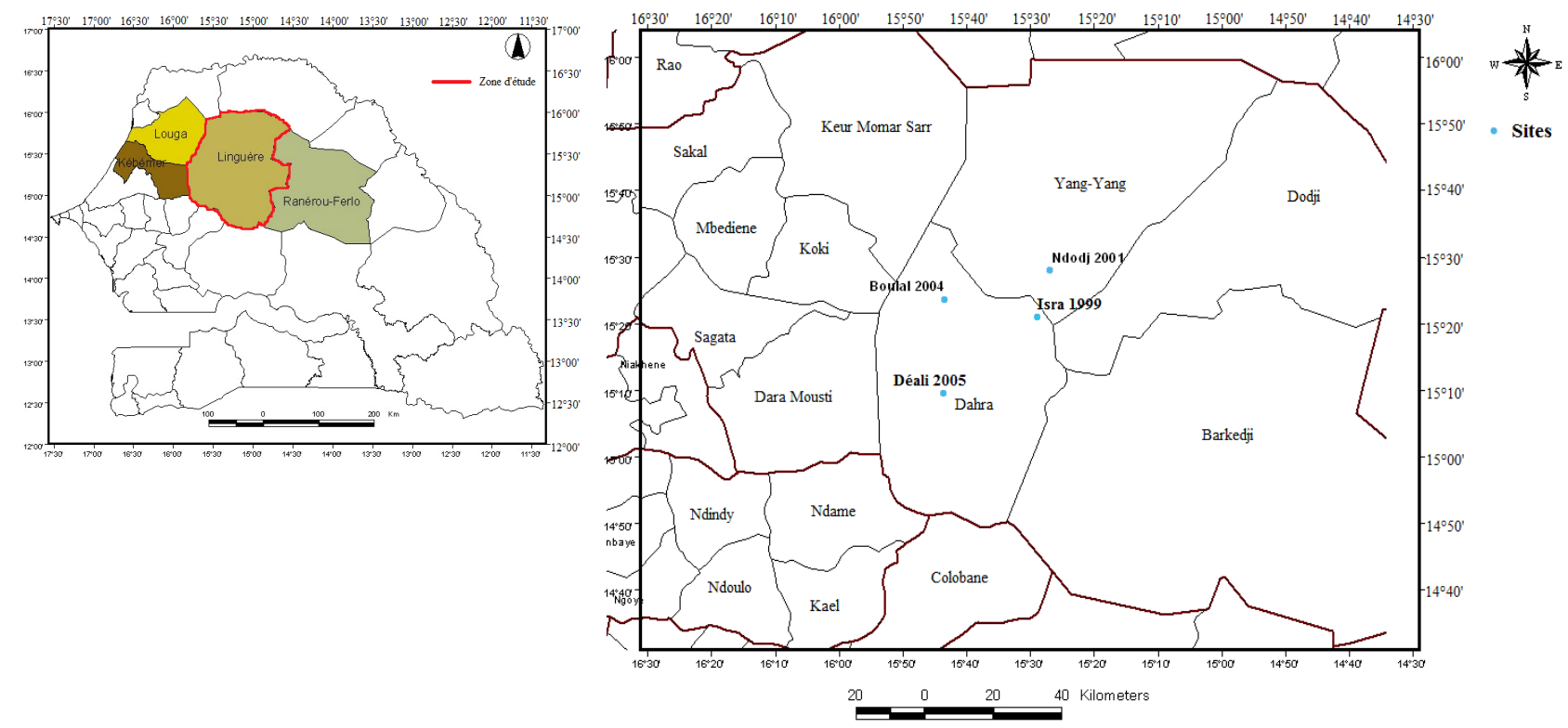

Figure 1. Sites location.

domly distributed in the four plantations based on geomorphic units (shelf, depression and dune) with three plots per unit, respectively $6,3,3$ and 6 plots in ISRA (10 years old plantations), Ndodj (8 years old plantations), Boulal (5 years old plantations) and deali (4 years old plantations). The following dendometric variables, a total of 489 trees were measured: crown height, crown diameter, stem diameter at the breast height, stem basal diameter (at $0.30 \mathrm{~m}$ ) and the height from the tree base to first branch. All measurements were taken in meters using measuring tape except the total tree height where clinometers were included. The distance between the ground level and the base of the live crown was also measured by raising the tip of the measuring tape with a meter rule to the base of the first branch of the tree. Crown height was estimated as the total height minus the distance from the ground level to the base of the live crown. As tree crown may not form a perfect cycle, the crown diameter was estimated by taking the average measurements of the longest and the shortest diameters of the crown zone. Crown ratio was estimated as the crown diameter divided by total tree height. Stem diameter (D) at breast height at the standard of $1.37 \mathrm{~m}$ above ground level [25,26], was taken by measuring the circumference $(\mathrm{C})$ of the stem. The stem diameter was calculated as follows: $\mathrm{C}=\mathrm{D} \times \pi$, $\mathrm{D}=\mathrm{C} / \pi$, where $\pi=22 / 7$.

\subsection{Analysis}

Acacia senegal trees distribution within population and according to the sites was adjusted to the Weibull function, commonly nowadays used in Forestry surveys [27-29].
The Weibull distribution is as follows:

$$
f(x)=\frac{a}{b}\left(\frac{x-a}{b}\right)^{c-1} \exp \left[-\left(\frac{x-a}{b}\right)^{c}\right]
$$

$a=$ position parameter; $b=$ scale parameter or size parameter; $c=$ form parameter linked with the observed structure.

Trees DBH or trees height distributions were adjusted to Weibull function with Minitab 16 Software. The Simple Linear Regression analyses were carried out on the dendrometic parameter using the statistical software Statistica.

A mathematical model was developed to estimate the tree age (dependent variable) from the dendometric variables. In order to control the homoscedasticity of regression residuals and correct distribution of variables, a Box-Cox transformation was performed on crown diameter and height from base to first branch.

\section{Results}

Stem diameter at the breast height (DBH) Classes' Distribution of A. Senegal Trees Figure 2 showed the class distribution of the Acacia senegal trees stem diameter at the breast height $(\mathrm{DBH})$ according to the different ages. The Weibull distribution of Acacia Senegal trees per DBH classes shows a left dissymmetric bell shaped curve with $\mathrm{c}$ form coefficient comprised between 1 and 3.6 for the 10,8 and 5 years old plantations. This value of $\mathrm{c}$ means that the stands were dominated by young trees. The $\mathrm{c}$ value of the 4 years old plantation is inferior to 1 indicating a reversed $\mathrm{J}$ distribution. 


\subsection{Total height Classes' Distribution of A. senegal Trees}

The total height classes' distribution of A. Senegal within different year old plantation adjusted to Weibull distribution showed bell-shaped form with left distribution $(1<\mathrm{c}$ $<3.6$ ) indicating a predominance of individuals with small height in the stands like the diameter class distribution. In the 10 and 8 years old, trees of height class (3.0$4.5 \mathrm{~m})$ and $(2.4 \mathrm{~m}-2.8 \mathrm{~m})$ were respectively dominant in the stands whereas $(3.2-4.8 \mathrm{~m})$ was the dominant class in the 5 and 4 years old plantations (Figure 3 ).

\subsection{Estimation Equations of Dendometric Parameters of $A$. senegal}

The descriptive statistics summary of the trees age and dendometric parameters were presented in Table 1. The minimum and maximum of tree age recorded in this study was 4 and 10 respectively. The mean of 489 trees age was 9.14. The minimum and maximum Stem diameters at breast height were 0.0 and $210.00 \mathrm{~cm}$ respectively, with the mean of $64.48 \mathrm{~cm}$ from the 489 trees. The stem basal diameter varied from a minimum of $10.00 \mathrm{~cm}$ to a maximum of $103.00 \mathrm{~cm}$ with a mean of $36.73 \mathrm{~cm}$. The crown diameter varied from a minimum of $0.95 \mathrm{~m}$ to a
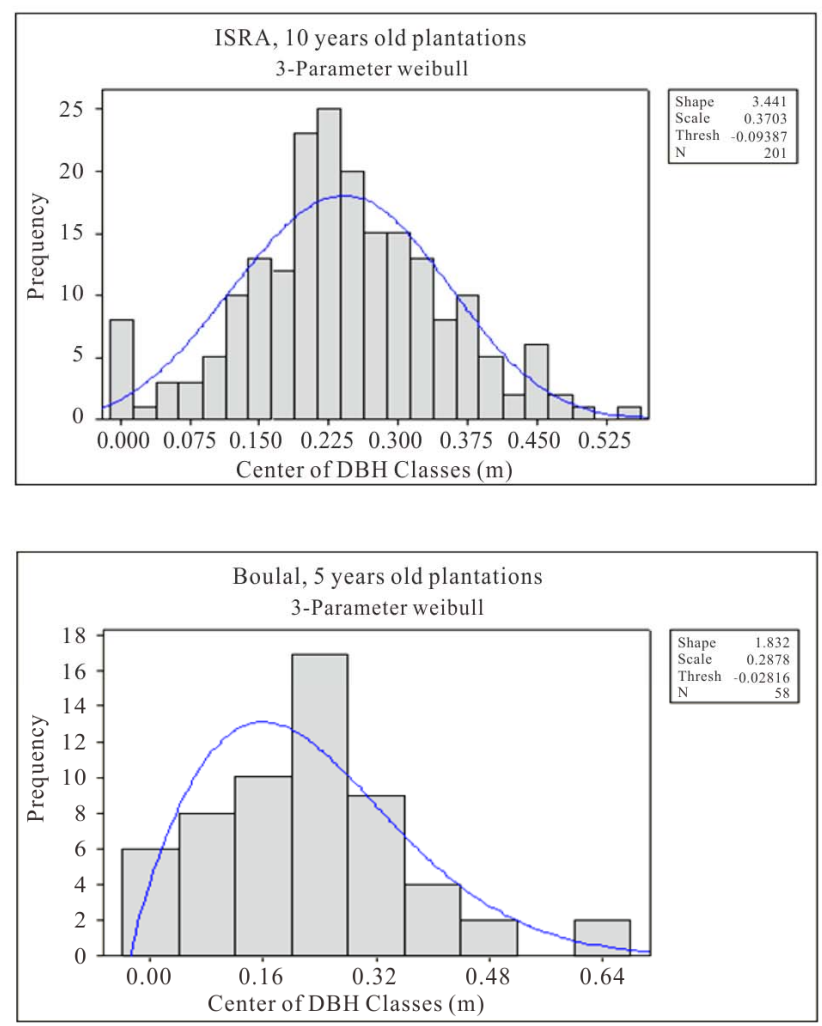

maximum of $7.85 \mathrm{~m}$ with a mean of $3.56 \mathrm{~m}$. Stem diameters at breast height, stem basal diameter, crown diameter and crown depth were the predictor variables used in the regression analysis.

The result also revealed positive correlations between Stem diameters at breast height ,stem basal diameter, crown diameter, crown depth and tree height, crown depth and crown diameter which were highly significant $(\mathrm{p}=0.00)$ (Table 2).

The values of Pearson correlation coefficients of determination $\left(\mathrm{R}^{2}\right)$ between the stem diameter at breast, height and crown diameter, crown diameter and depth crown diameter and crown depth, crown depth and height were respectively $0.60,0.78,0.77$, and 0.99 .

Weaker correlations were found with tree height and crown depth when the stem diameter at breast height was taken as predictor variable than crown diameter.

The prediction models for stem diameter at breast height, height, crown depth and crown diameter with stem basal diameter as predictor variable were also presented. Graphs of the relationships between stem diameter at breast height and crown diameter, crown depth and height, crown diameter and height, crown diameter and crown depth showed positive relationships (Figure 4).
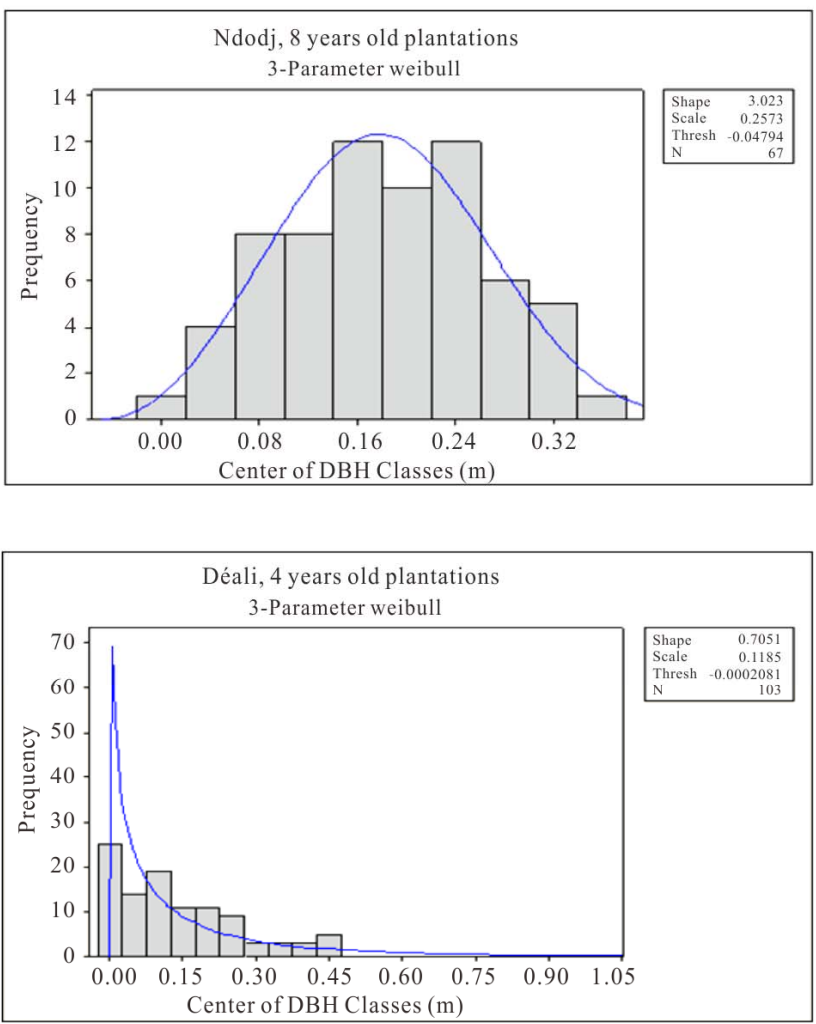

Figrure 2. Stem diameter at the breast height Classes' Distribution of the different years old plantations. 

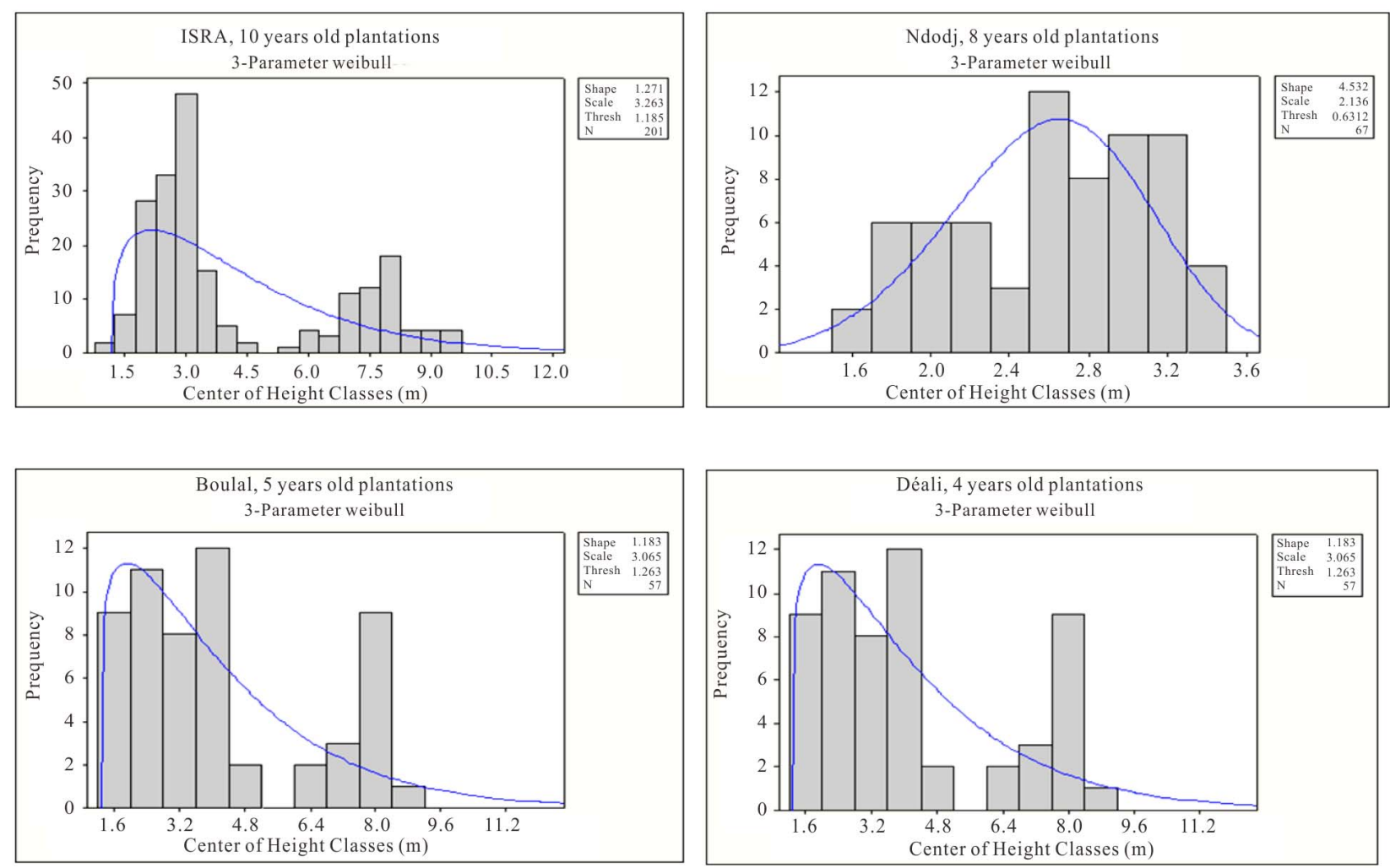

Figure 3. Total height Classes' Distribution of the different years old plantations.

Table 1. Summary of descriptive statistics of the data used in regression and correlation analysis.

\begin{tabular}{lcccccc}
\hline \multicolumn{1}{c}{ Variables } & Mean & CV (\%) & Minimum & Median & Maximum & Skewness \\
\hline Age & 9.14 & 29.58 & 4.00 & 8.00 & 10.00 & -0.09 \\
Basal diameter & 36.73 & 47.05 & 10.00 & 34.00 & 103.00 & 0.92 \\
Stem diameter at breast height cm & 64.48 & 61.08 & 0.0 & 63.00 & 210.00 & 0.36 \\
Height(m) & 3.39 & 60.46 & 0.90 & 2.80 & 9.50 & 1.44 \\
Height from base to first branch (m) & 8.43 & 130.74 & 0.35 & 5.00 & 90.00 & 2.85 \\
Crown ratio & 1.18 & 29.11 & 0.48 & 1.18 & 4.30 & 1.64 \\
Crown diameter (m) & 3.56 & 36.95 & 0.95 & 3.40 & 7.85 & 0.48 \\
\hline
\end{tabular}

Table 2. Regression prediction model, correlation coefficient of determination $\left(R^{2}\right)$ of the different tree dimensions.

\begin{tabular}{|c|c|c|c|}
\hline Variables & Prediction model & $\mathrm{R}^{2}$ & Probability \\
\hline Stem diameter at breast height vs. Stem basal diameter & $\mathrm{y}=0.11+1.45 * x$ & 0.41 & 0.000 \\
\hline Height vs. Stem basal diameter & $\mathrm{y}=1.41+5.41 * x$ & 0.21 & 0.000 \\
\hline Crown depth vs. Stem basal diameter & $y=1.33+5.40 * x$ & 0.21 & 0.000 \\
\hline Crown diameter vs. Stem basal diameter & $y=1.81+4.76 * x$ & 0.39 & 0.000 \\
\hline Height vs. Stem diameter at breast height & $y=1.46+3.00 * x$ & 0.33 & 0.000 \\
\hline Crown depth vs. Stem diameter at breast height & $y=1.40+2.96 * x$ & 0.33 & 0.000 \\
\hline Crown diameter vs. Stem diameter at breast height & $y=1.89+2.60 * x$ & 0.60 & 0.000 \\
\hline Height vs. Crown depth & $\mathrm{y}=0.05+1.01 * x$ & 0.99 & 0.000 \\
\hline Height vs. Crown diameter & $\mathrm{y}=-0.91+1.21 * x$ & 0.78 & 0.000 \\
\hline Crown depth vs. Crown diameter & $\mathrm{y}=-0.92+1.19 * \mathrm{x}$ & 0.77 & 0.000 \\
\hline
\end{tabular}



of Acacia senegal in the Senegalese Semi-Arid Zone-Ferlo

Table 3. Regression coefficients of the predictor variables.

\begin{tabular}{lccccc}
\hline \multicolumn{1}{c}{ Predictor } & Coef & SE Coef & T & P & VIF \\
\hline Constant & -35.80 & 2.71 & -13.21 & 0.00 & \\
Stem basal diameter (SBD) & -0.05 & 0.01 & -6.78 & 0.00 & 1.8 \\
$\begin{array}{l}\text { Stem diameter at breast height (DBH) } \\
\text { Height from the base to the first ramification }\end{array}$ & 0.01 & 0.004 & 2.33 & 0.02 & 3.0 \\
$\begin{array}{l}\text { (HBFR)*(m) } \\
\text { Crown diameter (CD)* }\end{array}$ & 0.17 & 0.08 & 2.17 & 0.03 & 1.2 \\
Height (m) & 1.33 & 0.53 & 2.51 & 0.01 & 1.2 \\
\hline
\end{tabular}

$\mathrm{R}-\mathrm{Sq}=49.1 \%$, variables having undergone Box-Cox transformation

Table 4. Global signification of the model.

\begin{tabular}{lccccc}
\hline \multicolumn{1}{c}{ Source } & DF & SS & MS & F & P \\
\hline Regression & 6 & 1752.14 & 292.02 & 77.43 & 0.00 \\
Residual Error & 482 & 1817.84 & 3.77 & & \\
Total & 488 & 3569.98 & & & \\
\hline
\end{tabular}
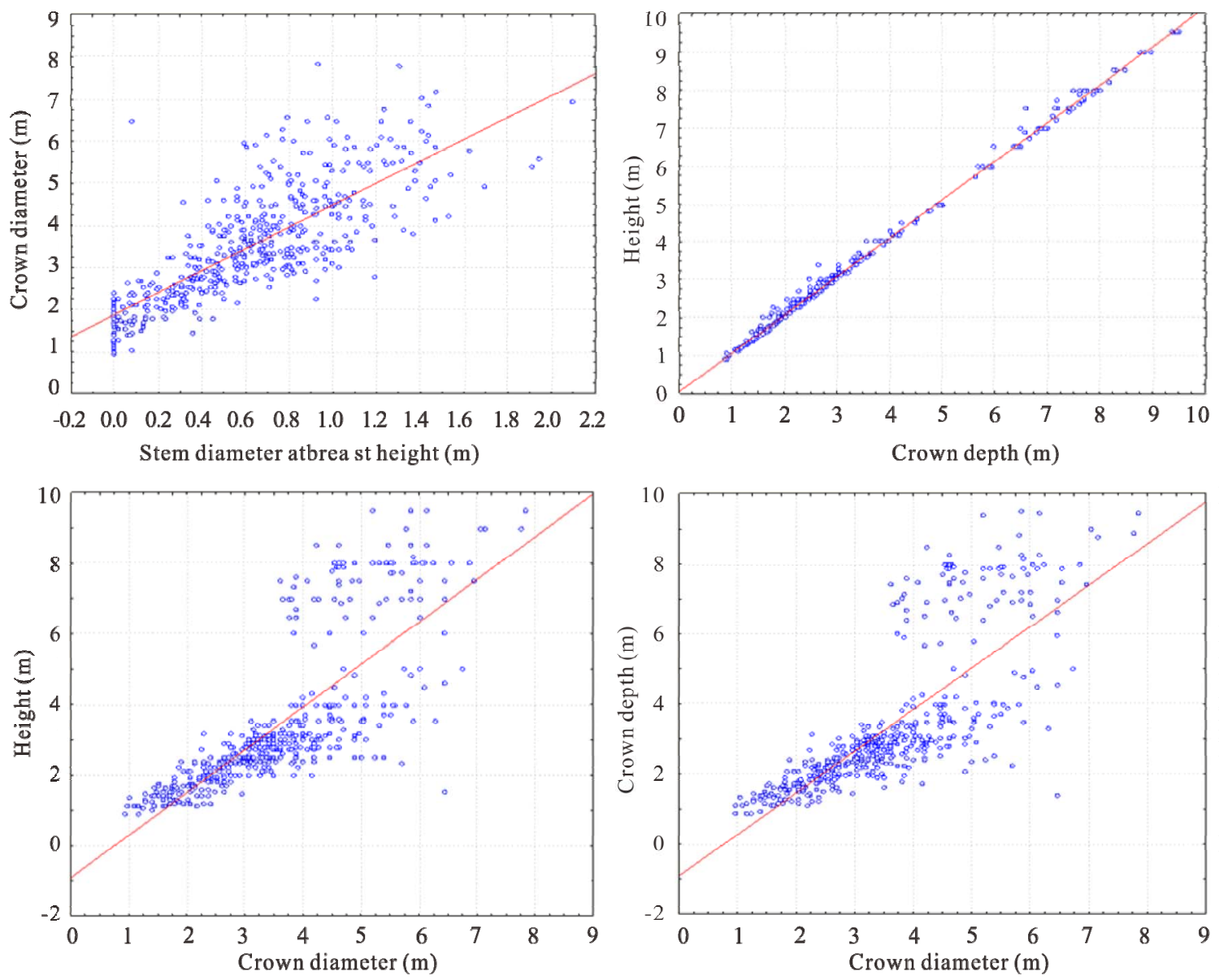

Figure 4. Scatterplots with regression lines showing the strong relationship between dendrometric parameters. 


\subsection{Estimation Equations of $A$. senegal Age}

All variables except height had a significant regressioncoefficient (Table 3). Values of variance inflation below 5 variables indicated that the regression coefficients were well estimated. The age of Acacia Senegal could be estimated by the mathematical model: Age $=-35.8-0.05$ $\mathrm{SBD}+0.01 \mathrm{DBH}+0.17$ HBFR0. $04+1.33 \mathrm{CD} 0.46$. This model is globally highly significant (Table 4). It could, however, explain only $49.1 \%$ of the total variation (Table 3).

\section{Discussion}

The observed diameter structure for the 10, 8 and 5 years old plantations shows a left dissymetric distribution observed $(1<\mathrm{c}<3.6)$ meant a predominance of individuals with small diameter (DBH) in the stands [30]. The assessment of the distribution of a stand especially a population, is of great interest for the sustainable management of forest resources by evaluating readily available and future planning of the samples [31]. This distribution can be used to predict the threat of extinction in the medium or long-term species threat exacerbated by an operation that fails to implement intervention measures to reverse this processs [32].

The examination of the diametric structure reveals populations with low regeneration; the maintenance over the long term is compromised, showing very irregular structures characterized by the scarcity of individuals in small diameter classes. The diameter classes (DBH) which dominate the studied populations is a characteristic of Sahelian vegetation. Large diameter trees are rare. This scarcity reflects the inability of the trees to grow normally in thickness due to accumulated moisture deficits.

Study of the relationships of stem diameters at breast height, stem basal diameter, crown diameter and crown depth as independent variables against tree height, crown depth, of A. Senegal revealed significant positive correlations. These findings are consistent with [8] who established positive significant relationships between stem diameter as an independent variable against tree height, crown height and crown diameter of P. biglobosa growing in the Nigerian guinea savanna. Our results suggested that when compared to stem diameter at breast height, taking the crown diameter as a predictor variable to predict tree height and crow depth will yield greater accuracy due to the stronger correlation found in this relationship. However, according to [8], crown diameter was less accurate to estimate tree height and crown depth than stem diameter at breast height. The crown diameter of $A$. senegal can be estimated by stem diameter at breast height as the relationship gives a relatively high signifi- cant correlation $\left(\mathrm{R}^{2}=0.60\right)$. [33] found stronger correlation between stem diameter and crown diameter $\left(\mathrm{R}^{2} \geq\right.$ 0.74) of Combretum spp. and two species of Searsia. As for A. Senegal age estimation, the established model is not strong as it can explain only $49.1 \%$ of the age variation.

\section{Conclusions}

Ecological structure of the different year old A. senegal plantation revealed a bell-shaped form with left dissymmetric distribution indicating a predominance of individuals with small diameter at breast height.

Allometry study of A. Senegal showed positive correlations between stem diameter at breast height, stem basal diameter, tree height, crown diameter and crown depth.

Positive correlations were also found between crown diameter, tree height and crown depth. Prediction models derived from these relationships can be used to estimate the tree height, stem diameter at breast height and crown depth from crown diameter with greater precision. Estimating the tree height and crown depth from stem diameter at breast height will yield result with less accuracy because of the weaker correlations.

\section{REFERENCES}

[1] C. J. Chiveu, O. G. Dangasuk and F. N. Wachiira, "Quantitative Variation among Kenyan Populations of Acacia senegal (L.) Wild. for Gum Production, Seed and Growth Traits," New Forests, Vol. 38, No. 1, 2009, pp. 1-14. doi:10.1007/s11056-008-9128-1

[2] P. Soloviev, C. Zerbo, D. Lompo, L. B. Yoda, D. Jacques and A. Diallo, "Acacia senegalau Burkina Faso: État de la Ressource et Potentielproductif," Bois et Forêts des Tropiques, Vol. 300, No. 2, 2009, pp. 15-25.

[3] J. P. M. Brenan, "Manuel Sur la Taxonomiedes Espèces d'acacias," Fao, Rome, 1983, 53 pages.

[4] P. L. Giffard, "L’arbre Dans le Paysage Sénégalais. Sylviculture en Zone Tropicale Sèche," Centre Technique Forestier Tropical, Paris, 1974, 431 pages.

[5] C. W. Fagg and G. E. Allison, "Acaciasenegal and Gum Arabic Trade," Tropical Forest Papers No. 42, Oxford Forestry Institute, 2004.

[6] H. J. Von Maydell, "Arbres et Arbustesdu Sahel. Leurscaractéristiques et Leurs Utilisations," Gtz, Eschborn, 1983, 531 pages.

[7] J. Vassal and M. Dione, "Les Acacias Gommifères au Sahel: Exsudation Gommière et Production" Perspectives Proceedings of the 5th Sahel Worshop in Natural Resources and Social Conflicts in the Sahel, Sondeborg, 4-6 January 1993, pp. 180-191.

[8] T. Buba, "Prediction Equations for Estimating Tree Height, Crown Diameter, Crown Height and Crown Ratio of Parkia Biglobosa in the Nigerian Guinea Savanna," African 
Journal of Agricultural Research, Vol. 7, No. 49, 2012, pp. 6541- 6543 .

[9] A. H. Arzai and B. S. Aliyu, "The Relationship between Canopy Width, Height and Trunk Size in Some Tree Species Growing in the Savanna Zone of Nigeria," Bayero Journal of Pure and Applied Sciences, Vol. 3, No. 1, 2010, pp. 260-263.

[10] J. Paula, E. Peper, G. McPherson and S. M. Mori, "Equations for Predicting Diameter, Height, Crown Width, and Leaf Area of San Joaquin Valley Street Trees," Journal of Arboric, Vol. 27, No. 6, 2001, pp. 306-317.

[11] R. W. Aaron, “Alterations in Douglas-Fir Crown Structure, Morphology, and Dynamics Imposed by the Swiss Needle Cast Disease in the Oregon Coast Range," M.S. Thesis, Oregon State University, 2003, p. 405.

[12] P. A. Tanka, "Prediction of Distribution for Total Height and Crown Ratio Using Normal versus Other Distributions", M.S. Thesis, Graduate Faculty of Auburn University, 2006, p. 92.

[13] S. Turan, "Diameter at Breast Height-Crown Diameter Prediction Models for Picea orientalis," African Journal of Agricultural Research, Vol. 4, No. 3, 2009, pp. 215219.

[14] R. Villalba and T. T. Veblen, "Improving Estimates of Total Tree Ages Based on Increment Core Samples," Ecoscience, Vol. 4, No. 4, 1997, pp. 534-542.

[15] C. Wong and P. Lertzman, "Errors in Estimating Tree Age: Implications for Studies of Stand Dynamics," Canadian Journal of Forest Research, Vol. 31, No. 7, 2001, pp. 1262-1271. doi:10.1139/x01-060

[16] S. L. Gustell and E. A. Johnson, “Accurately Ageing Trees and Examining Their Height-Growth Rates: Implications for Interpreting Forest Dynamics," Journal of Ecology, Vol. 90, No. 1, 2002, pp. 153-166. doi:10.1046/j.0022-0477.2001.00646.x

[17] V. Rozas, "Tree Age Estimates in Fagus sylvatica and Quercus robur: Testing Previous and Improved Methods," Plant Ecology, Vol. 167, No. 2, 2003, pp. 193-212. doi:10.1023/A:1023969822044

[18] H. Poupon, "La Biomasseet l'évolution de la Croissance d'Acaciasenegal Sous Unesavanesahélienne (Sénégal)", Revue Bois et Forets des Tropiques, Vol. 166, 1976, pp. 23-38.

[19] A. Wane, V. Ancey and B.Grosdidier, "Les Unités Pastorales du Sahel sénégalais, Outil de Gestion de L'élevage et des Espaces Pastoraux. Projet Durable Ouprojetde Développement Durable," Développement Durable \& Territoires, Dossier 8: Méthodologies et Pratiques Territoriales de l'évaluation en Matière de Développement Durable, 2006, p. 18.

http://developpementdurable.revues.org/index3292.html

[20] G. Faye, P. L. Frison, S. Wade, J. A. Ndione, A. C. Beye and J. P. Rudant, "Etude de la Saisonnalité des Mesures des Diffusiomètres Scat: Apport au Suivi de la Végétation au Sahel, Cas du Ferlo au Sénégal," Rev Télédétection,
Vol. 10, No. 1, 2011, pp. 23-31.

[21] K. Niang, "L'arbre Dans les Parcourscommunautairesdu Ferlo-Nord (Sénégal)," Mémoire de DEA FST/UCAD, 2009 , p. 67.

[22] J. C. Diouf, L. E. Akpo, G. Gintzburger and A. Ickowicz, "Dynamics of Rangeland Vegetation over a Thirty Year Period in the Senegalese Pastoral Semi-Arid Zone", 7th International Rangeland Congress, Durban, July 2003.

[23] A. Richter, H. Grossmann and H. Thiele, "Beitrage zur Methodik der Holzvorratsinventuren auf mathematischstatistischer Grundlage," Arch.Forstwes, Vol. 2, 1953, pp. 142-181.

[24] J. Parde, "Dendrométrie," 1ére édition. Nancy (France): Ecole Nationale des Eaux et Forêts, Imprimerie LousJean, 1961, p. 350.

[25] Nature Conservation Practice Note, "Measurement of Diameter at Breast Height (DBH)," 2006, pp. 1-6. http://www.afcd.gov.hk/english/conservation/con_tech/fil es/common/NCPN_No.02_measurement_of_DBḦ_ver.2 006.pdf

[26] A. Ngomanda, Q. M. Mavouroulou, N. L. E. Obiang, D. M. Ionga, J. F. Mavoungou, N. Lepengue, N. Picard and B. Mbatchi, "Derivation of Diameter Measurements for Buttressed Trees, an Example from Gabon," Journal of Tropical Ecology, Vol. 28, No. 3, 2012, pp. 1-4. doi:10.1017/S0266467412000144

[27] R. L. Bailey and T. R. Dell, "Quantifying Diameter Distributions with the Weibull Function," Journal of Forest Science, Vol. 19, No. 2, 1973, pp. 97-104.

[28] J. Rondeux, "Les Mesures des Arbres et des Peuplements Forestiers," Presses Agronomiques de Gembloux, Gembloux, 1993, p. 521.

[29] W. Bonou, R. Glèlè-Kakaï, A. E. Assogbadjo, H. N. Fonton and B. Sinsin, "Characterization of Afzelia africana $\mathrm{Sm}$. Habitat in the Lama Forest Reserve of Benin," Forest Ecology and Management, Vol. 258, No. 7, 2009, pp. 1084-1092. doi:10.1016/j.foreco.2009.05.032

[30] B. Husch, T. Beers and J. Kershaw, "Forest Mensuration," 4th Edition, Ronald Press Company, London, 2003.

[31] H. N. Fonton and P. Sagbo, "Modélisation des Distributions des Paramètres Dendrométriques d'une Espèce Ligneuse Dominante en Peuplement Naturel," Annals of Forest Science, Vol. 61, No. 6, 2004, pp. 545-549. doi:10.1051/forest:2004049

[32] E. Semereab, J. Philippart and J. L. Doucet, "Evaluation de la Présence de Forêts a Haute Valeur Pour la Conservation Dans la Concession Forestière Attribuée à Gau Services (Cameroun) Selon le Concept Défini par le Principe du Forest Stewardship Council," Nature + asbl, Gembloux, 2010, p. 57.

[33] G. H. Stoffberg, M. W. Rooyen, M. J.Linde and H. T. Groeneveld, "Modelling Dimensional Growth of Three Street Tree Species in the Urban Forest of the City of Tshwane," Southern Forests: A Journal of Forest Science, Vol. 71, No. 4, 2009, p. 4. 